УДК [504.43+504.73].054: 547.912

\title{
НАКОПЛЕНИЕ БЕНЗ[А]ПИРЕНА В РАСТЕНИЯХ РАЗНЫХ ВИДОВ И ОРГАНОГЕННОМ ГОРИЗОНТЕ ПОЧВ СТЕПНЫХ ФИТОЦЕНОЗОВ ПРИ ТЕХНОГЕННОМ ЗАГРЯЗНЕНИИ
}

\author{
Сушкова Светлана Николаевна ${ }^{1}$, \\ terra_rossa@mail.ru
}

\section{Яковлева Евгения Вячеславовна², kaleeva@ib.komisc.ru}

\author{
Минкина Татьяна Михайловна', \\ tminkina@mail.ru
}

\section{Габов Дмитрий Николаевич2, gabov@ib.komisc.ru}

\section{Антоненко Елена Михайловна ${ }^{1}$, antonenko1102@yandex.ru}

1 Южный федеральный университет, Россия, 344090, г. Ростов-на-Дону, пр. Стачки, 194/1.

\author{
Дудникова Тамара Сергеевна 1 , \\ tyto98@yandex.ru
}

\author{
Барбашев Андрей Игоревич 1 , \\ barbashev_andrei@mail.ru
}
Минникова Татьяна Владимировна' loko261008@yandex.ru

\author{
Колесников Сергей Ильич ${ }^{1}$, \\ kolesnikov@sfedu.ru
}

Раджпут Вишну Даял, rajput.vishnu@gmail.com
2 Институт биологии Федерального исследовательского центра Коми научного центра Уральского отделения Российской академии наук,
Россия, 167982, г. Сыктывкар, ул. Коммунистическая, 28.

\begin{abstract}
Актуальность. Несмотря на значительное количество работ по исследованию загрязнения объектов окружающей среды полиаренами, недостаточно сведений о накоплении полициклических ароматических уәлеводородов и, в частности, наиболее токсичного бенз[а]пирена разными видами травянистых растений, что обусловливает актуальность исследований в данном направлении. Проведено изучение распределения бенз[а]пирена по органам растений и органогенным горизонтам почв зоны воздействия Новочеркасской ГРЭС.

Цель: выявить закономерности накопления бенз[а]пирена в растениях разных видов и органогенном горизонте почв степных фитоценозов в зависимости от удаления от Новочеркасской ГРЭС.

Объекты. В зоне действия Новочеркасской ГРЭС был проведен отбор проб надземной и корневой частей растений и подстилающих их органогенных горизонтов почв на глубину 0-20 см. Для исследования на мониторинговых площадках нами были выбраны доминантные виды травянистых растений: амброзия полыннолистная (Ambrosia artemisifolia L.), полынь австрийская (Artemisia austriaca Jack.), тысячелистник благородный (Achillea nobilis L), иикорий обыкновенный (Cichorium intybus L.), пижма обыкновенная (Tanacetum vulgare L.), пырей ползучий (Elytrigia repens (L.) Nevski.). Также были исследованы злаковые культуры: овсюг (Avena fatua), пшеница (Triticum aestivum L.), овес (Avena sativa L.), овсяница валлисская, или типчак (Festuca valesiaca L.), тростник обыкновенный (Phragmites australis L.), мятлик луговой (Poap retense L.).

Методы. Содержание бенз[а]пирена в образцах растений определяли модифицированным методом омыления. Модификация предполагает замену трехразовой экстракции этоксиэтаном, являющимся прекурсором, на н-гексан. Извлечение поллютанта растворителем проводили после удаления мещающих липидных макрокомпонентов растений, предварительно подвергая кипячению образец в 2-\% растворе гидрооксида калия. Определение концентрации бенз[а]пирена осуществляли на хроматографре Agilent 1260 с фрлуориметрическим детектором.

Результаты. На основании кластерного анализа выявлены три группы травянистых растений по уровню содержания бенз[а]пирена: слабого, среднего и активного накопления. Максимальные уровни накопления бенз[а]пирена выявлены для типчака, минимальные для амброзии. Установлено, что массовая доля бенз[а]пирена в почвах и растениях закономерно снижалась по мере удаления от предприятия. Максимальное загрязнение было выявлено по трансекте генерального направления, в 1,6 км от источника. Наименее загрязненными были площадки, заложенные в восточном направлении. Исследование накопления бенз[а]пирена в разных органах растений показало, что наибольшим загрязнением отличались корни всех исследованных видов. Массовая доля бенз[а]пирена в органогенном горизонте почв значительно превышала его содержание в растениях разных видов.
\end{abstract}

\section{Ключевые слова:}

Бенз[а]пирен, сжигание угля, травянистые растения, почва, биоаккумуляция, техногенное загрязнение.

\section{Введение}

Химическое загрязнение почв чаще всего образуется за счет попадания смеси веществ в неорганической и органической формах на поверхность почвенных объектов. Полициклические ароматические углеводороды (ПАУ) являются органическими загрязнителями и побочными продуктами многих отраслей промышленности. К природным источникам ПАУ относят горные породы и минералы, природные лес- ные и степные пожары, нефть и нефтепродукты, вулканическую деятельность [1]. Антропогенными источниками ПАУ в окружающей среде являются предприятия теплоэнергетического комплекса и работа автомобильного транспорта, добыча и переработка полезных ископаемых [2-4]. Основной вклад в загрязнение окружающей среды ПАУ вносит работа и функционирование предприятий теплоэнергетического комплекса. В процессе сжигания угля с выбросами 
в воздух попадают не только тяжелые металлы, но и ПАУ. Распространение ПАУ в объектах наземных экосистем обусловлено рядом факторов, таких как летучесть, коэффициент разбавления [5]. Низкомолекулярные ПАУ, имеющие 2 или 3 бензольных кольца, больше склонны в абиотической диссипации или улетучиванию, чем ПАУ с высокой молекулярной массой (4-6 бензольных колец). Однако такие ПАУ имеют низкую растворимость и высокую степень абсорбции на поверхности $[6,7]$. Установлено образование техногенных ореолов различной плотности при скоплении углеводородов, образующихся на промышленных предприятиях, с распространением ПАУ за пределы санитарно-защитной зоны предприятия [8, 9]. Е.Ю. Константиновой с соавторами при изучении селитебной зоны, зоны влияния Антипинского нефтеперерабатывающего завода и ТЭЦ-2 (г. Тюмень) обнаружено наибольшее содержание нафталина, флуорена, фенантрена, антрацена, флуорантена, пирена, бенз[а]антрацена, бенз[h]флуорантена, бенз[к]флуорантена, бенз[а]пирена, дибенз[а,h]антрацена, бенз[ghi]перилена в поверхностных горизонтах почв импактных зон [10].

Среди всех ПАУ, попадающих или находящихся в наземных экосистемах, наибольшую токсичность оказывает бенз[а]пирен (БаП) [11-13]. БаП в почве оказывает токсическое воздействие на состояние и функционирование наземных экосистем. Чувствительность флоры к ПАУ зависит от видовых особенностей самих растений, а также интенсивности влияния промышленности на окружающую среду. В настоящее время при мониторинговых исследованиях загрязнения биоценозов ПАУ чаще всего используют сообщества мхов и лишайников, так как представители их видов имеют высокий биоаккумуляционный потенциал к накоплению ПАУ [14-19]. Исследования Л.И. Белых с использованием расчета коэффициента биологического поглощенияудержания позволили разграничить растения на группы согласно их способности накапливать БаП из почвы [20]. Группу со слабой способностью биоаккумуляции составили представители корнеклубнеплодов; группу с повышенной способностью к биоаккумуляции - зерновые культуры.

При оценке канцерогенной опасности, связанной с накоплением ПАУ в сельскохозяйственной продукции, выращиваемой вблизи промышленных зон, было установлено, что наиболее опасны овощи, надземные части которых используются в пищу, т. к. надземная часть испытывает прямое техногенное воздействие от предприятий, где ПАУ попадают на поверхность листьев или стеблей по пути выбросов «атмосферарастение» [21]. Однако в работе J. Feng et al. [22] при мониторинге сельскохозяйственных угодий, в которых основным источником содержания ПАУ в почве является сжигание соломы после уборки урожая, показано, что суммарное содержание ПАУ в пшенице уменьшается от корня к стеблю. При этом суммарное содержание ПАУ снижается по мере роста пшеницы от зоны перехода корня в стебель и в зоне перехода стебля в колос. Похожие результаты описаны в ис- следовании K. Tian et al. [23]. Как сообщает автор, суммарное содержание ПАУ в пшенице снижается от корня к стеблю, где частично содержание высокомолекулярных ПАУ в надземной части обусловлено аэротехногенным загрязнением. Объяснить это можно тем, что поглощение из воды и почвы через корни растений является основным путем проникновения ПАУ в растения, поэтому они больше адсорбируются на поверхности корней, а затем переходят в клеточные стенки соседних клеток, накапливаются в них и далее переходят и накапливаются в вакуолях. Высокомолекулярные ПАУ представляют большую угрозу для здоровья людей [24]. Как показывает ряд исследований, колос пшеницы имеет низкий биоконцентрационный отклик на загрязнение почв ПАУ и неблагоприятной обстановкой для этих культур является загрязнение приземного слоя воздуха [23, 25, 26]. Адсорбция ПАУ надземной частью растений зависит от морфологических и физиологических характеристик листьев. Особенности физиологического строения растений зависят от природно-климатических условий произрастания.

В степных регионах юга России, таких как Ростовская область, широко распространены травянистые растения. В том числе ареалы произрастания степных травянистых растений зачастую расположены в санитарно-защитной зоне и зоне наблюдения практически всех предприятий теплоэнергетического комплекса Ростовской области $[27,28]$. Существует ряд работ, посвященных исследованию воздействия промышленности на изменение состава почв и травянистых растений в районах воздействия предприятий теплоэнергетического комплекса $[12,20]$. Так, изучен качественный и количественный состав органических загрязнителей почвы и растений промышленной зоны Тайшетского шпалопропиточного завода. Результаты свидетельствуют, что наибольшим накоплением ПАУ отличается вегетационная и корневая масса травянистых растений, по сравнению с корой и стволом деревьев широколиственных пород [28]. В работе Q. Yang et al. [29] отмечалось, что в многолетних травах суммарное содержание 16 ПАУ выше, чем в однолетних, а в целом суммарное содержание ПАУ в травянистой и кустарниковой растительности выше, чем в древесных культурах. Исследования воздействия угольных шахт на содержание ПАУ в растениях южной тундры позволили выявить, что травянистые растения, благодаря своей высокой аккумулятивной способности, вносят значительный вклад (около 10 \%) в накопление ПАУ в тундровых фитоценозах $[30,31]$. Важное влияние на накопление ПАУ оказывают видовые и биоморфологические особенности растений [31]. Обнаружена способность листьев Tilia euchlora к высокой степени биоаккумуляции бенз[а]пирена, по сравнению с листьями Pyrus calleryana [32]. Работы, посвященные исследованию концентраций ПАУ в листьях Quercus ilex, а также эпифитном мхе Leptodon smithii, характерных для городского агроценоза, показали, что максимальной биоаккумуляционной способностью обладают листья дуба, имеющие мощную восковую кутикулу, которые активнее аккумулирова- 
ли ПАУ, по сравнению со мхом. Однако низко- и высокомолекулярные ПАУ накапливались во мхах, произрастающих в условиях урбанизированных городских территорий [33]. В результате изучения биоаккумуляции ПАУ вегетативной массой кизила (Cornus mas), клена (Acer pseudoplatanus) и лещины обыкновенной (Corylus avellana) установлено, что листья лещины отличались более высоким коэффициентом поглощения-удержания, а кленовые листья позволили отнести растения вида листопадных деревянистых кустарников и деревьев рода Лещина (Corylus) семейства Берёзовые (Betulaceae) к наиболее важным видам при оценке коэффициента поглощения-удержания ПАУ листовым покровом лесов, за счет высокого показателя индекса площади листа [34].

Зональными типами растительности Ростовской области являются разнотравно-дерновиннозлаковые, бедноразнотравно-дерновиннозлаковые, а также полынно-дерновиннозлаковые степи $[35,36]$. Ростовская область является регионом с развитой сельскохозяйственной отраслью, в структуре земельного фонда которой доля распаханных земель составляет $87 \%$, земель поселений - 4 \%, земель промышленности 0,9\%, а земель, особо охраняемых природных территорий, - 0,1 \% [37]. Несмотря на то, что земли промышленности занимают менее 1 \% общей площади региона, на территории области расположено несколько крупных предприятий, в том числе Новочеркасская ГРЭС, что может оказывать негативное влияние на немногочисленные участки с естественной растительностью и представлять угрозу для возделывания сельскохозяйственных культур. Элементы-примеси каменного угля, используемого в качестве основного топлива на предприятии, обогащены значительны количеством ПАУ. В селитебной зоне Новочеркасской ГРЭС расположено несколько населенных пунктов и водных объектов (рис. 1). Несмотря на значительное количество работ по исследованию загрязнения объектов окружающей среды ПАУ, недостаточно сведений об их накоплении, и в частности наиболее токсичного БаП, разными видами травянистых растений. Так как деятельность Новочеркасской ГРЭС общепризнана основным источником ПАУ в атмосфере [38], исследования характера загрязнения почв и травянистых растений в зоне действия Новочеркасской ГРЭС, представляют значительный интерес. Ранее было исследовано влияние выбросов тяжелых металлов на травянистые растения селитебной и санитарной защитной зоны [39]. Важно оценить дальность распространения БаП от предприятия, выявить видовые особенности накопления БаП растениями, их зависимость от биоморфологических показателей.

Цель работы - исследовать закономерности накопления бенз[а]пирена в почвах и травянистых растениях степной зоны на разном расстоянии от Новочеркасской ГРЭС.

\section{Материалы и методь}

В 2014 г. в зоне действия Новочеркасской ГРЭС был проведен отбор проб надземной и корневой частей растений и подстилающих их органогенных го- ризонтов почв на глубину 0-20 см. Пробы отбирали в трех повторностях. Точки отбора проб представлены на рис. 1. Для исследования на мониторинговых площадках нами были выбраны доминантные виды травянистых растений: амброзия полыннолистная (Ambrosia artemisiifolia L.), полынь австрийская (Artemisia austriaca Jack.), тысячелистник благородный (Achillea nobilis L), цикорий обыкновенный (Cichorium intybus L.), пижма обыкновенная (Tanacetum vulgare L.), пырей ползучий (Elytrigia repens (L.) Nevski.). Также были исследованы злаковые культуры: овсюг (Avena fatua), пшеница (Triticum aestivum L.), овес (Avena sativa L.), овсяница валлисская (Festuca valesiaca L.), тростник обыкновенный (Phragmites australis L.), мятлик луговой (Poap retense L.).

Исследуемая территория воздействия НчГРЭС и наблюдения условно поделена на две зоны. Площадки мониторинга, расположенные в северо-западном направлении, на расстоянии до 20 км от НчГРЭС, составляют генеральное направление (№ 4-5, 8-10). Генеральное направление отбора проб почвы и растений линейно пересекает селитебные зоны трех населенных пунктов: станица Кривянская, г. Новочеркасск, станица Грушевская. Вторая условная зона состоит из площадок мониторинга, расположенных вокруг предприятия на расстоянии до 3 км: площадки № 1, 2, 3, 6, 7, 11, 12.

В соответствии с преобладающим направлением и розой ветров на местности было установлено генеральное направление, расположенное по прямой линии максимального аэрального распределения выбросов НчГРЭС, проходящей от источника загрязнения через г. Новочеркасск и станицы Кривянской. Образцы почв и растений отбирали ежегодно по линии генерального направления на мониторинговых площадках № 4, 5, 8, 9, 10. Дополнительно были отобраны пробы вокруг НчГРЭС на площадках № 1, 2, 3, 6, 7, 11 и 12.

Для определения содержания БаП в пробах почв и растений использовали стандартный метод ПНД Ф 16.1:2.2:2.3:3.62-09 в модификации [40]. Отбор проб проведен согласно ГОСТ 27262-87 и ГОСТ 17.4.4.02.-83 [41, 42]. На первом этапе пробоподготовки почвы очищались от природных и техногенных включений. Растения предварительно сушились на воздухе и измельчались. Далее проводили омыление образца в 2 \% спиртовом растворе гидроксида калия с дальнейшей экстракцией БаП неполярным растворителем. Экстракция проведена троекратно. Растворитель этоксиэтан, рекомендуемый в методике, был заменен на н-гексан, т. к. этоксиэтан принадлежит к числу ядовитых и наркотических средств [43]. Далее экстракт БаП в н-гексане помещали в круглодонную колбу объемом 100 мл, и выпаривали содержимое на роторном испарителе при $42{ }^{\circ} \mathrm{C}$. Осадок в колбе растворяли в 1 мл ацетонитрила.

Содержание БаП в растворе ацетонитрила определяли методом высокоэффективной жидкостной хроматографии на хроматографе Agilent 1260 не позднее суток с момента окончания экстракции БаП. Хроматограф Agilent 1260 оснащен флуориметрическим детектором, в качестве адсорбента используется сили- 
кагель, в качестве жидкой фазы - ацетонитрил. Концентрацию БаП в экстракте находили, сравнивая полученный сигнал на хроматограмме экстракта со стандартным раствором БаП. Концентрацию рассчитывали по формуле:

$$
\mathrm{C}=\frac{S \cdot C_{0}}{S_{0}}
$$

где $S$ - площадь пика на хроматограмме экстракта БаП; $S_{0}$ - площадь пика на хроматограмме стандартного раствора БаП; $C$ - концентрация БаП в экстракте; $C_{0}-$ концентрация БаП в стандартном растворе

Кластерный анализ выполнен в программе Statistiса 6 методом Варда. Сходство накопления БаП растениями разных видов оценивалось по Евклидовому расстоянию.



Рис. 1. Схема расположения мониторинговых площадок в зоне влияния Новочеркасской ГРЭС

Fig. 1. Map layout of monitoring sites in the zone of influence of Novocherkasskaya SDPS

Таблица 1. Расположение площадок и характеристика типа почв

Table 1. Location of sites and characteristics of the type of soil

\begin{tabular}{|c|c|c|c|}
\hline $\begin{array}{l}\text { № площадки } \\
\text { Site number }\end{array}$ & $\begin{array}{l}\text { Координаты } \\
\text { Coordinates }\end{array}$ & $\begin{array}{c}\text { Удаленность от НчГРЭС } \\
\text { Distance from NcSDPS }\end{array}$ & Тип почв/Soil type \\
\hline 1 & $\begin{array}{l}\mathrm{X}-40^{\circ} 15^{\prime \prime} 035^{\prime \prime \prime} \\
Y-47^{\circ} 24^{\prime \prime} 432^{\prime \prime \prime}\end{array}$ & $\begin{array}{c}1,0 \text { км на северо-восток } \\
1,0 \mathrm{~km} \text { to the north east }\end{array}$ & \multirow{6}{*}{$\begin{array}{l}\text { Чернозем обыкновенный карбонатный среднемощный малогумусный } \\
\text { тяжелосуглинистый на лессовидных суглинках } \\
\text { Chernozem ordinary carbonate medium-power low-humus heavy loamy } \\
\text { loamy loam }\end{array}$} \\
\hline 4 & $\begin{array}{l}\mathrm{X}-40^{\circ} 12^{\prime \prime} 245^{\prime \prime \prime} \\
\mathrm{Y}-47^{\circ} 23^{\prime \prime} 941^{\prime \prime \prime}\end{array}$ & $\begin{array}{l}1,6 \text { км на северо-запад } \\
1,6 \mathrm{~km} \text { to the north-west }\end{array}$ & \\
\hline 5 & $\begin{array}{l}\mathrm{X}-40^{\circ} 12^{\prime \prime} 423^{\prime \prime \prime} \\
\mathrm{Y}-47^{\circ} 24^{\prime \prime} 129^{\prime \prime \prime}\end{array}$ & $\begin{array}{l}1,2 \text { км на северо-запад } \\
1,2 \mathrm{~km} \text { to the north-west }\end{array}$ & \\
\hline 7 & $\begin{array}{l}\mathrm{X}-40^{\circ} 13^{\prime \prime} 088^{\prime \prime \prime} \\
\mathrm{Y}-47^{\circ} 25^{\prime \prime} 280^{\prime \prime \prime}\end{array}$ & $\begin{array}{c}1,5 \mathrm{kм} \mathrm{на} \mathrm{север} \\
1,5 \mathrm{~km} \text { to the north }\end{array}$ & \\
\hline 9 & $\begin{array}{l}\mathrm{X}-40^{\circ} 01^{\prime \prime} 935^{\prime \prime \prime} ; \\
\mathrm{Y}-47^{\circ} 25^{\prime \prime} 595^{\prime \prime \prime}\end{array}$ & $\begin{array}{l}15 \mathrm{kм} \text { на северо-запад } \\
15 \mathrm{~km} \text { to the north-west }\end{array}$ & \\
\hline 10 & $\begin{array}{l}\mathrm{X}-40^{\circ} 01^{\prime \prime} 935^{\prime \prime \prime} \\
\mathrm{Y}-47^{\circ} 25^{\prime \prime} 737^{\prime \prime \prime}\end{array}$ & $\begin{array}{l}20 \mathrm{kм} \mathrm{на} \mathrm{северо-запад} \\
20 \mathrm{~km} \text { to the north west }\end{array}$ & \\
\hline 2 & $\begin{array}{l}X-40^{\circ} 12^{\prime \prime} 418^{\prime \prime \prime} \\
Y-47^{\circ} 22^{\prime \prime} 605^{\prime \prime \prime}\end{array}$ & $\begin{array}{c}3,0 \text { км на юго-запад } \\
3,0 \mathrm{~km} \text { to the south west }\end{array}$ & $\begin{array}{l}\text { Аллювиально-луговая карбонатная слабогумусированная песчаная на } \\
\text { аллювиальных отложениях } \\
\text { Alluvial meadow carbonate weakly humus sandy on alluvial deposits }\end{array}$ \\
\hline 3 & $\begin{array}{l}\mathrm{X}-40^{\circ} 11^{\prime \prime} 958^{\prime \prime \prime} \\
\mathrm{Y}-47^{\circ} 23^{\prime \prime} 231^{\prime \prime \prime}\end{array}$ & $\begin{array}{c}2,7 \text { км на юго-запад } \\
2,7 \mathrm{~km} \text { to the south west }\end{array}$ & $\begin{array}{l}\text { Лугово-черноземная пойменная малогумусная легкоглинистая на ал- } \\
\text { лювиальных отложениях } \\
\text { Meadow-chernozemic floodplain low humus clayey on alluvial deposits }\end{array}$ \\
\hline 6 & $\begin{array}{l}X-40^{\circ} 13^{\prime \prime} 116^{\prime \prime \prime} \\
Y-47^{\circ} 25^{\prime \prime} 271^{\prime \prime \prime}\end{array}$ & $\begin{array}{l}\text { 2,0 км на северо-северо- } \\
\text { запад } \\
2,0 \mathrm{~km} \text { to the north-north- } \\
\text { west }\end{array}$ & $\begin{array}{l}\text { Лугово-черноземная среднемощная малогумусная тяжелосуглинистая } \\
\text { на лессовидных суглинках } \\
\text { Meadow-chernozem medium-thick low-humus heavy loamy loess-like } \\
\text { loams }\end{array}$ \\
\hline 8 & $\begin{array}{l}\mathrm{X}-40^{\circ} 08^{\prime \prime} 313^{\prime \prime \prime} \\
\mathrm{Y}-47^{\circ} 23^{\prime \prime} 842^{\prime \prime \prime}\end{array}$ & $\begin{array}{l}5 \text { км на северо-запад } \\
5 \mathrm{~km} \text { to the north-west }\end{array}$ & $\begin{array}{l}\text { Лугово-черноземная среднемощная малогумусная тяжелосуглинистая } \\
\text { на лессовидных суглинках } \\
\text { Meadow-chernozem medium-thick low-humus heavy loamy loess-like loams }\end{array}$ \\
\hline 11 & $\begin{array}{l}\mathrm{X}-47^{\circ} 38^{\prime \prime} 959^{\prime \prime \prime} \\
\mathrm{Y}-40^{\circ} 23^{\prime \prime} 396^{\prime \prime \prime}\end{array}$ & $\begin{array}{c}1,0 \text { км на юго-восток } \\
1,0 \mathrm{~km} \text { south east }\end{array}$ & $\begin{array}{l}\text { Чернозем обыкновенный карбонатный среднемощный слабо- } \\
\text { гумусированный среднесуглинистый на лессовидных суглинках } \\
\text { Ordinary black carbonate medium-power, slightly humus, medium-loamy, } \\
\text { loamy loamy loam }\end{array}$ \\
\hline 12 & $\begin{array}{l}X-47^{\circ} 39^{\prime \prime} 602^{\prime \prime \prime} ; \\
Y-40^{\circ} 24^{\prime \prime} 456^{\prime \prime \prime}\end{array}$ & $\begin{array}{c}1,1 \text { км на юг } \\
1,1 \mathrm{~km} \text { to the south }\end{array}$ & $\begin{array}{l}\text { Аллювиально-луговая среднемощная малогумусная среднесуглинистая } \\
\text { на лессовидных суглинках/Alluvial-meadow medium-power low-humus } \\
\text { medium-loamy loamy loam }\end{array}$ \\
\hline
\end{tabular}




\section{Результаты и обсуждение}

Изменение содержания бенз[а]пирена в растениях. $\mathrm{C}$ целью определения сходства в накоплении БаП растениями разных видов был применен кластерный анализ (рис. 2). На основании полученных данных исследованные растения можно поделить на три группы по уровню накопления БаП: слабого, среднего и активного накопления. Для группы слабого накопления значения содержания БаП варьируют от 0,2 до 2,5 нг/г на разных мониторинговых площадках (табл. 2). К данной группе относятся растения семейства Астровые (Asteráceae): амброзия, пижма, тысячелистник и цикорий. У всех представленных видов сходное строение, плотные покрытые налетом листья, имеющие невысокую суммарную площадь поверхности, стебли с небольшой площадью, крупные одре- весневшие корни, проникающие в минеральные горизонты, что минимизирует способность БаП проникать внутрь растения.

К группе среднего поглощения можно отнести растения с уровнем накопления БаП от 0,6 (на более чистых участках) до 7,8 нг/г (на сильно загрязненных участках). Данная группа представлена злаковыми культурами (Gramíneae): мятликом, овсом, овсюгом, пшеницей и представителем семейства Астровые (Asteráceae) - полынью. Все злаковые виды характеризуются хорошо развитой мочковатой корневой системой, способствующей более активному накоплению поллютантов из почвы. У злаков тонкие мягкие листья, через устьица которых проникновение БаП не затруднено.



Pис. 2. Дендрограмма сходства в накоплении бенз[а]пирена растениями разньх видов, метод Варда

Fig. 2. Dendrogram of similarities in accumulation of benzo[a]pyrene by plants of different species, Ward's method

У полыни корневая система стержневая, с мощным корнем и множеством боковых ответвлений, сконцентрированных в органогенном горизонте почвы. Но в сравнении с амброзией и пижмой из группы слабого накопления, ее листья и стебли обильно покрыты волосками, что играет важную роль в удержании БаП на поверхности листового аппарата.

Группа активного накопления сильно отличается по поглощению от двух остальных групп и представлена растениями многолетних злаковых культур: пыреем, типчаком и тростником. Пырей и типчак характеризуются повышенной площадью надземной по- верхности и мощной мочковатой корневой системой, что объясняет их наивысшую способность к поглощению ПАУ. Тростник - довольно крупное и мощное растение со значительной площадью поверхности листьев, имеет мощное, толстое ползучее корневище и разветвленную корневую систему, что делает его активным аккумулятором БаП. Все виды изученной группы являлись многолетними растениями, что, вероятнее всего, может служить причиной высокого содержания в них БаП. Уровни содержания БаП в видах данной группы составили от 3,3 до 36,4 нг/г на разных мониторинговых площадках. 
Таблица 2. Содержание бенз[а]пирена в растениях разных видов и в органогенном горизонте почв (0-20 см) на мониторинговых площзадках в зоне действия Новочеркасской ГРЭС, нг/2

Table 2. Benzo[a]pyrene content in plants of different species and in organogenic soil horizon (0-20 cm) at monitoring sites in the area of operation of the Novocherkasskaya SDPS, $10^{-9} \cdot \mathrm{g} \cdot \mathrm{g}^{-1}$ soil

\begin{tabular}{|c|c|c|c|c|c|c|c|c|c|c|c|c|}
\hline \multirow{2}{*}{$\begin{array}{c}\text { Вид растения } \\
\text { Туре of plant }\end{array}$} & \multicolumn{12}{|c|}{ Номер мониторинговой площадки/Monitoring site number } \\
\hline & 1 & 2 & 3 & 4 & 5 & 6 & 7 & 8 & 9 & 10 & 11 & 12 \\
\hline \multirow{2}{*}{$\begin{array}{l}\text { Амброзия/Wormwood } \\
\text { Ragweed }\end{array}$} & $\underline{0,40}$ & $\underline{0,20}$ & $\underline{0,20}$ & 1,30 & $\underline{0,60}$ & $\underline{0,30}$ & $\underline{0,20}$ & $\underline{0,50}$ & $\underline{0,20}$ & $\underline{0,30}$ & 0,20 & $\underline{0,50}$ \\
\hline & $\overline{0,11}$ & 0,08 & $\overline{0,07}$ & $\overline{0,45}$ & $\overline{0,19}$ & $\overline{0,09}$ & 0,09 & $\overline{0,15}$ & $\overline{0,07}$ & $\overline{0,11}$ & $\overline{0,08}$ & $\overline{0,18}$ \\
\hline \multirow{2}{*}{ Мятлик/Bluegrass } & $\underline{1,50}$ & $\underline{0,70}$ & $\underline{0,90}$ & $\underline{5,40}$ & 2,40 & $\underline{1,30}$ & $\underline{0,80}$ & $\underline{1,80}$ & $\underline{0,90}$ & $\underline{1,00}$ & $\underline{0,90}$ & 1,90 \\
\hline & $\overline{0,87}$ & $\overline{0,13}$ & $\overline{0,13}$ & $\overline{1,52}$ & $\overline{0,25}$ & $\overline{0,15}$ & $\overline{0,14}$ & $\overline{0,23}$ & $\overline{0,14}$ & $\overline{0,23}$ & $\overline{0,12}$ & $\overline{0,34}$ \\
\hline \multirow{2}{*}{ Овес/Oats } & 1,60 & $\underline{0,80}$ & 1,05 & $\underline{5,72}$ & 2,64 & 1,40 & $\underline{0,90}$ & 2,00 & $\underline{0,90}$ & 1,10 & 1,00 & 2,12 \\
\hline & $\overline{0,34}$ & $\overline{0,13}$ & $\overline{0,21}$ & 1,54 & $\overline{0,56}$ & $\overline{0,23}$ & $\overline{0,16}$ & $\overline{0,43}$ & $\overline{0,16}$ & $\overline{0,21}$ & $\overline{0,25}$ & $\overline{0,56}$ \\
\hline \multirow[b]{2}{*}{ Овсюг/Oatmeal } & $\underline{1,92}$ & $\underline{0,95}$ & 1,26 & 7,32 & $\underline{3,01}$ & $\underline{1,70}$ & 1,00 & 2,37 & $\underline{1,15}$ & 1,39 & 1,20 & 2,50 \\
\hline & $\overline{0,13}$ & $\overline{0,14}$ & $\overline{0,56}$ & 1,56 & 0,76 & $\overline{0,34}$ & $\overline{0,44}$ & $\overline{0,78}$ & $\overline{0,56}$ & $\overline{0,34}$ & $\overline{0,23}$ & $\overline{0,89}$ \\
\hline \multirow{2}{*}{ Пижма/Tansy } & $\underline{0,74}$ & $\underline{0,32}$ & $\underline{0,44}$ & 2,57 & $\underline{1,10}$ & $\underline{0,60}$ & $\underline{0,41}$ & $\underline{0,91}$ & $\underline{0,43}$ & $\underline{0,52}$ & $\underline{0,44}$ & $\underline{0,90}$ \\
\hline & $\overline{0,34}$ & $\overline{0,09}$ & $\overline{0,13}$ & $\overline{0,65}$ & $\overline{0,34}$ & $\overline{0,17}$ & $\overline{0,14}$ & $\overline{0,21}$ & $\overline{0,08}$ & $\overline{0,14}$ & $\overline{0,11}$ & $\overline{0,19}$ \\
\hline \multirow{2}{*}{ Полынь/Austrian wormwood } & $\underline{2,12}$ & 1,04 & 1,39 & 7,85 & $\underline{3,42}$ & 1,92 & 1,24 & 2,60 & $\underline{1,25}$ & 1,52 & 1,41 & 2,85 \\
\hline & $\overline{0,14}$ & $\overline{0,11}$ & $\overline{0,34}$ & $\overline{1,53}$ & $\overline{0,76}$ & $\overline{0,23}$ & $\overline{0,12}$ & $\overline{0,43}$ & $\overline{0,12}$ & $\overline{0,15}$ & $\overline{0,11}$ & $\overline{0,45}$ \\
\hline \multirow{2}{*}{ Пырей/Tuberculus } & $\underline{7,55}$ & $\underline{3,62}$ & 4,70 & 27,81 & 12,21 & $\underline{6,73}$ & 4,21 & 9,53 & 4,51 & $\underline{5,30}$ & $\underline{4,96}$ & $\underline{10,04}$ \\
\hline & $\overline{1,11}$ & $\overline{0,45}$ & 0,65 & 2.67 & 2,45 & 1,68 & $\overline{0,98}$ & $\overline{1,43}$ & $\overline{0,88}$ & $\overline{0,98}$ & 1,11 & 2,16 \\
\hline \multirow{2}{*}{ Пшеница/Wheat } & $\underline{2,22}$ & 1,11 & 1,44 & $\underline{7,13}$ & $\underline{3,64}$ & $\underline{2,05}$ & 1,25 & 2,80 & 1,31 & 1,62 & 1,53 & $\underline{3,03}$ \\
\hline & 0,78 & $\overline{0,34}$ & 0,56 & 1,56 & 0,98 & $\overline{0,68}$ & $\overline{0,23}$ & $\overline{0,78}$ & $\overline{0,34}$ & $\overline{0,45}$ & $\overline{0,33}$ & 0,98 \\
\hline \multirow{2}{*}{ Типчак/Fescue } & 9,85 & 4,74 & 6,20 & 36,43 & 16,00 & $\underline{8,73}$ & 5,54 & 12,4 & $\underline{5,82}$ & $\underline{6,93}$ & 6,44 & 13,12 \\
\hline & $\overline{1,56}$ & $\overline{0,87}$ & 1,67 & 2,45 & 2,18 & $\underline{1,15}$ & $\overline{1,11}$ & 2,13 & $\overline{1,11}$ & $\overline{1,98}$ & $\overline{1,13}$ & 2,45 \\
\hline \multirow{2}{*}{ Тростник/Reed } & $\underline{8,90}$ & 4,34 & $\underline{5,91}$ & $\underline{33,00}$ & $\underline{14,54}$ & 7,94 & 10,21 & 9,93 & $\underline{5,32}$ & $\underline{5,93}$ & $\underline{5,34}$ & $\underline{10,91}$ \\
\hline & $\overline{1,78}$ & $\overline{0,99}$ & $\overline{1,21}$ & 2,68 & 2,34 & $\overline{1,08}$ & $\overline{1,78}$ & $\overline{2,14}$ & $\overline{1,13}$ & $\overline{1,23}$ & $\overline{1,10}$ & $\overline{2,11}$ \\
\hline \multirow{2}{*}{ Тысячелистник/Yarrow } & $\underline{0,70}$ & $\underline{0,55}$ & 2,01 & 2,40 & 1,24 & $\underline{0,94}$ & 1,04 & $\underline{0,81}$ & $\underline{0,61}$ & $\underline{0,61}$ & $\underline{0,81}$ & 1,14 \\
\hline & $\overline{0,11}$ & $\overline{0,11}$ & $\overline{0,25}$ & $\overline{0,13}$ & $\overline{0,13}$ & $\overline{0,16}$ & $\overline{0,15}$ & $\overline{0,14}$ & $\overline{0,14}$ & $\overline{0,15}$ & $\overline{0,22}$ & $\overline{0,24}$ \\
\hline \multirow{2}{*}{ Цикорий/Chicory } & $\underline{0,63}$ & 0,31 & $\underline{0,44}$ & 2,43 & 1,13 & $\underline{0,61}$ & 0,74 & $\underline{0,73}$ & $\underline{0,41}$ & $\underline{0,41}$ & $\underline{0,44}$ & $\underline{0,80}$ \\
\hline & $\overline{0,12}$ & $\overline{0,11}$ & $\overline{0,13}$ & 0,25 & $\overline{0,36}$ & $\overline{0,15}$ & $\overline{0,15}$ & $\overline{0,23}$ & $\overline{0,13}$ & $\overline{0,13}$ & $\overline{0,12}$ & $\overline{0,14}$ \\
\hline \multirow{2}{*}{ Почва/Soil } & 49,44 & $\underline{30,92}$ & $\underline{31,22}$ & 205,03 & 113,74 & 48,15 & 34,08 & $\underline{59,03}$ & 91,43 & 69,40 & 57,30 & 74,52 \\
\hline & $\overline{15,57}$ & 11,36 & $\overline{10,78}$ & 21,47 & 12,66 & $\overline{12,90}$ & $\overline{14,61}$ & $\overline{16,81}$ & $\overline{20,70}$ & $\overline{19,64}$ & $\overline{19,45}$ & $\overline{16,52}$ \\
\hline
\end{tabular}

Над чертой - среднее значение, под чертой-стандартное отклонение среднего.

Above the line is the average value, below the line is the standard deviation of the mean.

Исследование почв показало, что наибольшее накопление БаП характерно для образцов, отобранных на мониторинговой площадке № 4 (1,6 км к северо-западу от теплоэлектростанции) и на площадке № 5, находящейся севернее и ближе к источнику. Содержание БаП в растениях всех видов снижалось в 2 раза, возможно, это было связано с отклонением данной точки от основного потока переноса ПАУ. По площадке № 4, содержащей наибольшее количество БаП $(205$ нг/Г), можно построить следующий ряд из изучаемых растений 3 групп накопления, нг/г: типчак $(36,4)>$ тростник $(33,0)>$ пырей $(27,8)>$ полынь $(7,8)>$ овсюг $(7,3)>$ пшеница $(7,1)>$ овес $(5,7)>$ мятлик $(5,4)>$ пижма $(2,6)>$ цикорий $(2,43)>$ тысячелистник $(2,4)>$ амброзия $(1,3)$.

Помимо морфологического строения растений большую роль играет расстояние от источника БаП и сопутствующие источники загрязнения почв ПАУ, как автомагистрали вблизи площадок № 8-10. С удалением от источника загрязнения на площадке № 8 (5 км от НчГРЭС по ведущему (генеральному) направлению розы ветров) происходило трехкратное снижение содержания БаП во всех растениях по сравнению с полученными данными на площадке № 4, находящейся на расстоянии 1,6 км от НчГРЭС по ведущему (генеральному) направлению розы ветров. Такие же значения выявлены на площадке № 12 $(1,1$ км к югу от НчГРЭС). В растениях мониторинговой площадки № 9 (15 км от НчГРЭС) снижение содержания БаП достигало 5-6 раз по сравнению с площадкой № 4 (1,6 км от НчГРЭС по ведущему (генеральному) направлению розы ветров). С дальнейшим удалением на площадке № 10 (20 км от НчГРЭС) не наблюдали снижения содержания БаП в растениях относительно 15 км расстояния, выявлен даже незначительный рост уровня накопления БаП в растениях (в 1,2 раза). Вероятнее всего, это связано с близким расположением площадки мониторинга к автомагистрали (350 м), соединяющей пос. Новоперсиановка со станицей Грушевской. Исследования в зоне действия Тайшерского ШПЗ позволили выявить закономерное снижение содержания ПАУ в почве и травосмеси по мере удаления от источника и от автомобильных трасс. Отмечалось снижение содержания ПАУ в 5 раз по мере удаления от завода с 5 до 10 км, и в 20 раз с 5 до 15 км [14].

При рассмотрении площадок № 2 и 3, расположенных к юго-западу от Новочеркасской ГРЭС, было выявлено снижение содержания БаП в растениях по сравнению с максимальным уровнем загрязнения (площадка №4) в 5-6 раз на площадке № 3 (2,7 км к юго-западу), более смещенной к западу, и в 6-7 раз на площадке № 2 (3 км к юго-западу), расположенной южнее. Подобный уровень загрязнения отмечен в точке № 11 (на 1 км северо-восточнее предприятия). Таким образом, загрязнение в этих точках было на уровне загрязнения в 15-20 км от Новочеркасской ГРЭС на линии генерального направления. Содержание БаП в растениях, отобранных на почве площадки мониторинга № 4 в 4 раза выше, чем в растениях, 
отобранных с почв площадок № 1 (1 км северо-восток от источника) и № 6 (2 км на северо-запад). Поскольку растения данных площадок представлены одинаковыми видами, по сравнению с максимально загрязненной площадкой № 4, можно сделать вывод о том, что преимущественным фактором накопления БаП в растениях изученной территории является распределение выбросов Новочеркасской ГРЭС в зависимости от преобладающего направления розы ветров на местности.

Полученные данные позволяют подтвердить правильность выбора генерального направления перемещения органических загрязнителей от НчГРЭС по результатам кластерного анализа (рис. 3). Минимальное распространение БаП было характерно для восточного направления. Следует отметить, что для всех исследуемых растений, кроме тысячелистника, представленные кратности превышения были очень близкими. Для тысячелистника они были ниже по сравнению с другими растениями для большинства исследуемых площадок, возможно, это связано с его низкой способностью к биоаккумуляции БаП, даже в условиях максимального загрязнения, с которым проводились сравнения.

Для пшеницы, овса и амброзии на мониторинговой площадке № 4 выявлены значительные превышения (до 12 раз) содержания БаП в корнях над соцветиями, это может быть связано с повышенным уровнем загрязнения на данной площадке. Здесь корневая система растений находится под воздействием сильного загрязнения почвы, как следствие накопления значительных количеств БаП.

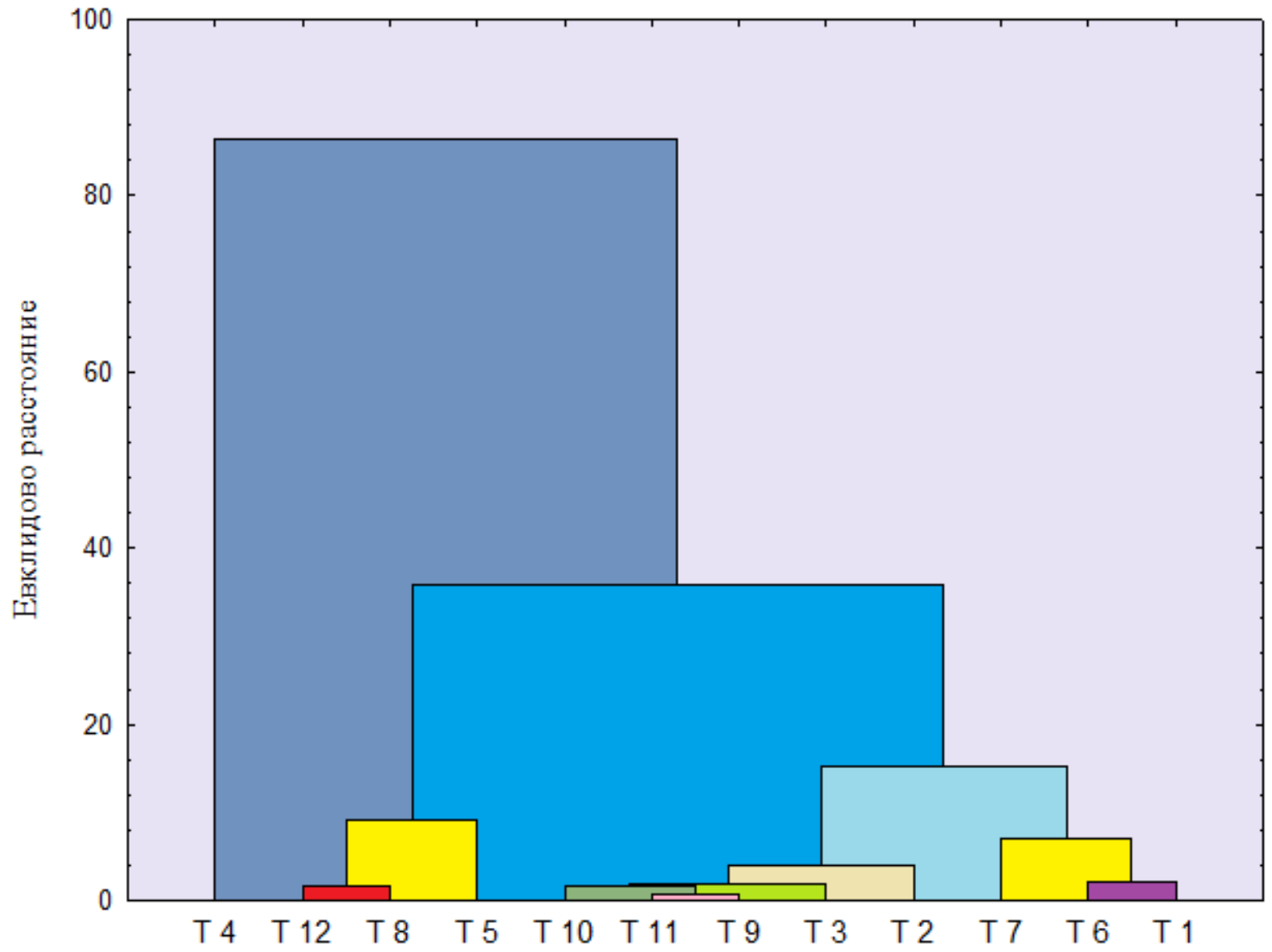

Рис. 3. Дендраграмма сходства в накоплении бенз[а]пирена растениями на разном удалении от Новочеркасской ГРЭС, метод Варда

Fig. 3. Dendrogram of similarities in accumulation of benzo[a]pyrene by plants at different distances from Novocherkasskaya SDPS, Ward's method

Однако содержание БаП в соцветиях мало отличается от значений на других мониторинговых площадках. Массовая доля БаП в органогенном горизонте почв была значительно выше содержания в растениях - от 137-423 раз для амброзии до 5-15 раз для типчака, на разных мониторинговых площадках. Наши предыдущие исследования травянистых растений в тундровой зоне подтверждают текущие результаты. В Deschampsia caespitosa и Festuca ovina, отобранных на фоновой почве, суммарное содержание
ПАУ ниже в 3-5 и 2-2,5 раз соответственно, чем у растений с загрязненных участков почвы [31].

На основании полученной дендрограммы можно констатировать, что содержание БаП в растениях всех видов сильно отличалось на мониторинговой площадке № 4, где происходило максимальное накопление БаП. В отдельный кластер объединялись площадки № 5, 8 (точки генерального направления) и 12 (1 км к югу от НчГРЭС), где загрязнение оставалось довольно высоким, но в 2-3 раза ниже, чем на пло- 
щадке № 4. Точки со средним уровнем загрязнения площадки № 1, 6, 7, расположенные в 1-2 км к северу, северо-востоку от предприятия, также формировали отдельный кластер. В еще один кластер объединялись наиболее чистые участки, удаленные на 15-20 км по генеральному северо-западному направлению: площадки № 9 и 10 и площадки юго-западного № 2 и 3 (2-3 км от НчГРЭС) и северо-восточного направления № 11 (1 км от НчГРЭС). Из всех исследованных видов растений максимальные уровни накопления БаП выявлены для типчака, минимальные - для амброзии. Таким образом, следует отметить, что активность накопления ПАУ растениями во многом зависела от их биоморфологических характеристик: строения корневой системы, площади и формы листьев, размера растения и др.

Изменение содержания бенз[а]пирена в почве. Coдержание ПАУ в верхнем слое почв площадок мониторинга меняется в зависимости от расположения и удаленности площадки от НчГРЭС. Содержание БаП в органогенных горизонтах почв (0-20 см) изменялось подобным образом, наименьшие уровни загрязнения были отмечены на мониторинговых площадках № 2, 3 и 7 , с максимумом накопления в точке № 4. Содержание БаП в почвах площадки мониторинга № 4 в 2 раза выше, чем в почвах площадки мониторинга № 2, в 3 раза выше, чем в почвах площадок № 8, 12 и в 4 раза выше по сравнению с почвами площадок мониторинга № 1 и 6. Кратность полученных результатов относительно содержания БаП в почве площадки мониторинга № 4 к другим участкам зоны влияния предприятия соответствует кратности содержания БаП в растениях, произрастающих на тех же площадках мониторинга. Содержание БаП в почве площадки № 5 снижалось в 2 раза, на площадке № 8 и 12 установлено снижение в 3 раза, по сравнению с максимальным загрязнением. Массовая доля БаП в почве на мониторинговых площадках № 1 и 6 была в 4 раза ниже, чем в условиях наивысшего загрязнения на площадке № 4, что также совпадает с данными, полученными для растений.

При этом для почв характерны довольно высокие уровни загрязнения на площадках № 9 и 10, значительно удаленных от источника, содержание БаП в них снижается лишь в 2-3 раза по сравнению с расстоянием 1,6 км в северо-западном направлении. С учетом того, что на площадке № 8 в 5 км от НчГРЭС в этом же направлении отмечено трехкратное снижение содержания ПАУ в почвах, можно предположить, что на массовую долю БаП в почве значительное влияние оказывает близкое расположение автотранспортных магистралей. Для растений также наблюдали влияние выбросов автотранспорта на площадке № 10, в случае почв, находящихся под антропогенным воздействием более долгое время, повидимому, имеет место старое загрязнение, не отразившееся на растениях на участке № 9. Несмотря на то, что уровни загрязнения БаП почв площадок № 9 и 10 достаточно высокие, в том числе за счет автомагистрали, проходящей возле города Новочеркасска и станицы Грушевской, интенсивность накопления БаП органами растений, в частности корневой системы, была в 4-6 раз ниже, чем на площадке № 4. На площадке № 8 за станицей Кривянской, подверженной воздействию автотранспорта и выбросов НчГРЭС, накопление БаП корнями растений было выше, чем на площадках № 9 и 10, но ниже, чем на площадке № 4, в 3 раза.

Изменение накопления бенз[а]пирена озимой пменицей и типчаком. Для оценки распределения БаП между органами растений проводили сравнение типичной сельскохозяйственной культуры региона озимой пшеницы (Triticum aestivum L.) [44], и сорного лугового растения - овсяницы валисской, или типчака (Festuca valesiaca L.) (рис. 4, 5). Согласно табл. 2, озимая пшеница относится к растениям среднего накопления БаП, а типчак - к группе активного накопления БаП. В этой части исследования необходимо оценить распределение БаП по органам растений: корням, стеблям и соцветиям (колосу). Минимальное накопление БаП было характерно для колосьев пшеницы и соцветий типчака - 0,33-1,43 и 1,83-14,16 нг/г, что, возможно, связано в первую очередь со временем накопления поллютанта данными частями растений. Также вышеуказанные особенности накопления БаП могут быть связаны с физиологическим и морфологическим строением растений, периодом отбора и развития растений. Как следствие этих факторов зафиксирована меньшая аккумуляция выбросов Новочеркасской ГРЭС. Акропетальная направленность в накоплении БаП свидетельствует об активном поглощении ПАУ из почвы.

Кратности превышения содержания ПАУ в корнях над стеблями на большинстве площадок составляли 2-3 раза, в корнях над соцветиями - в 4-6 раз. Следует отметить, что на всех исследованных участках содержание БаП в 2 до 10 раз превысило ПДК для почвы (20 нг/г). При сравнении накопления БаП вегетативными органами пшеницы и типчака установлено максимальное накопление в корнях, побегах и соцветиях на участке № 4, а минимальное - № 2.

Накопление БаП органами озимой пшеницы имело отличный от типчака характер (рис. 4). Содержание БаП в колосьях варьировалось от 0,22 (площадка № 2) до 1,42 нг/г (площадка № 4). В наземной вегетативной части озимой пшеницы наблюдали похожую разницу между минимальным значением - 0,75 (площадка № 2), и максимальным - 3,6 нг/г (площадка № 4). При этом разница между минимальным и максимальным значениями для соцветий и вегетативной массы составила 4 и 5 раз, соответственно. Однако разница между максимальным и минимальным значением для корневой зоны была значительно больше - 8 раз. У типчака распределение для соцветий, стеблей и корней было одинаковым и составило 8 раз (рис. 5). Такое накопление БаП в большем количестве корневой системой пшеницы обусловлено коротким периодом вегетации (до 280 дней, включая зимний период) и потребностью в элементах питания. Однако вместе с питательными элементами в пшеницу из почвы поступал БаП. Разница между содержанием БаП в корнях, стеблях и соцветиях пшеницы и типчака составляет 4,8 и 10 раз, соответственно. 


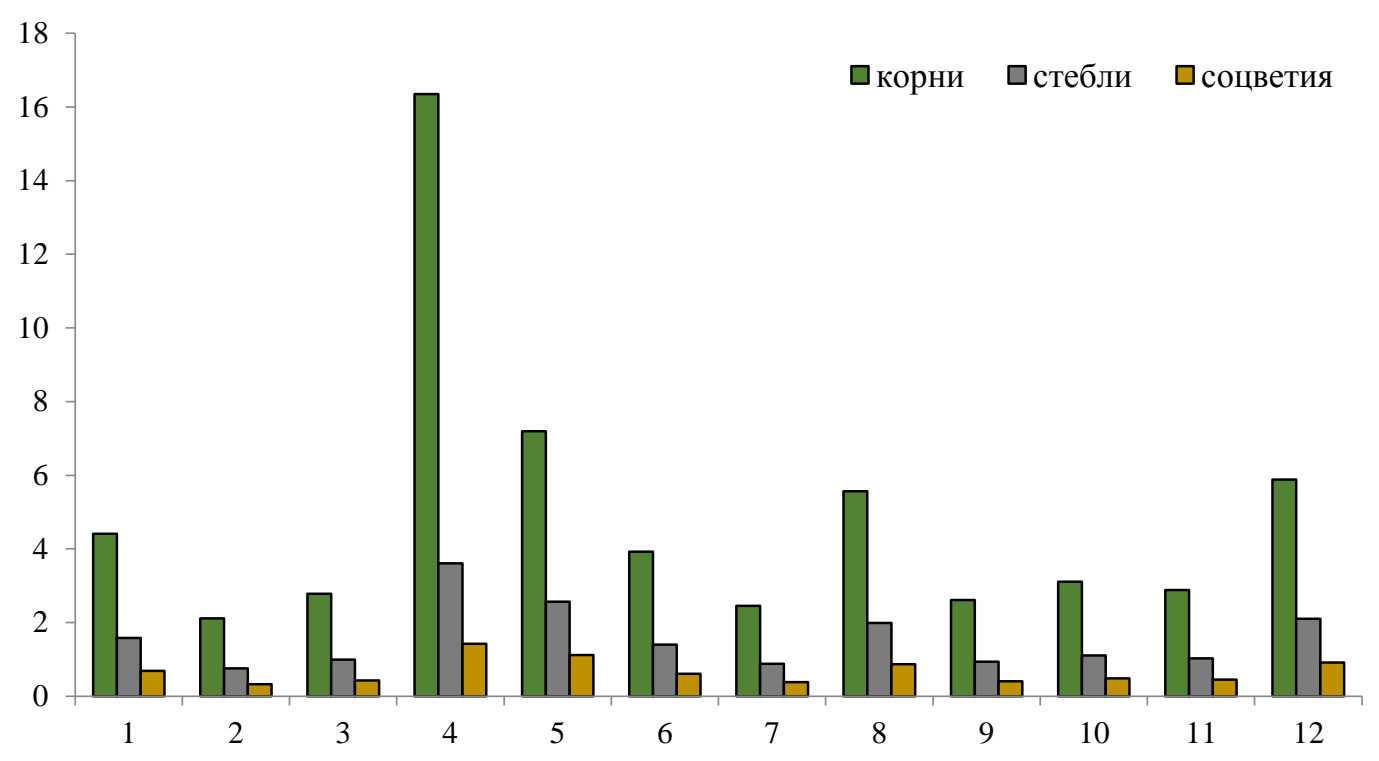

Pис. 4. Распределение бенз[а]пирена по органам пшениць озимой (Triticum аеstivuт L.) на разных мониторинговых площадках Новочеркасской ГРЭС, нг/2 почвы

Fig. 4. Benz[a]pyrene distribution over winter wheat (Triticum aestivum L.) organs at different monitoring sites of Novocherkasskaya SDPS, $\mu \mathrm{g} \cdot \mathrm{kg}^{-1}$ soil



Puc. 5. Распределение бенз[а]пирена по органам типчака (Festuca valesiaca L.) на разных мониторинговых площадках Новочеркасской ГРЭС, нг/2 почвы

Fig. 5. Benz[a]pyrene distribution over fescue (Festuca valesiaca L.) organs at different monitoring sites of Novocherkasskaya SDPS, $\mu \mathrm{g} \cdot \mathrm{kg}^{-1}$ soil

По данным табл. 2 максимальное содержание БаП в типчаке составило 36,4 нг/г, а в растениях озимой пшеницы содержание БаП установлено в 5 раз меньше $(7,1$ нг/г) по сравнению с типчаком обыкновенным. Индикация накопления БаП в почве и исследование аккумуляции выбросов на основании анализа данных двух видов растений, по накоплению БаП вегетативной массой и корневой системой, основано на широкой распространенности ареала произрастания данных видов, что делает их привлекательными для биомониторинга. Различия в накоплении БаП могут быть основаны на времени накопления токсиканта однолетними и многолетними растениями, поскольку БаП слабо подвергается деструкции и крайне персистентен, что повышает его устойчивость и способность к накоплению многолетними растениями. Для однолетних растений, вероятнее всего, индикаторная роль к накоплению БаП за ограниченный период времени, т. е. за полный период вегетации, - от 4 до 6 месяцев.

Из всех площадок мониторинга, испытывающих воздействие автотранспорта, только на площадке № 8 содержание БаП в органах пшеницы и типчака отличалось от содержания на остальных полях. Как видно из рис. 4 , содержание БаП в корневой системе озимой пшеницы было ниже, чем на площадке № 4, в 3 раза, но выше, чем на других площадках, в 2-3 раза. 
Накопление в стебле и колосе типчака мало отличается от подобного накопления на других площадках за исключением площадки № 4. Для типчака на площадке № 8 наблюдали похожие тенденции к накоплению БаП в корневой системе растения. В стебле и соцветии типчака на площадке № 8 по сравнению с озимой пшеницей наблюдали большее содержание БаП, чем в пшенице площадок зоны наблюдения НчГРЭС за исключением площадок № 4 и 5.

Озимая пшеница - это наиболее популярная однолетняя зерновая культура в регионе. Полный период выращивания составляет более 200 дней, из которых на зимний период приходится порядка 120-150 суток, а на активную вегетацию от стадии кущения до созревания зерна - до 100 суток. Поскольку функционирование НчГРЭС осуществляется непрерывно, в том числе в течение зимы и начале весны, оседание и депонирование ПАУ и тяжелых металлов происходит аэральным путем как с поверхности почвы, так и при зимней аккумуляции в снежном покрове. Вероятно, именно этим и обусловлено высокое содержание БаП в корневой системе растения, по сравнению со стеблями и колосками, что также объясняется персистентностью данного соединения, имеющего особенность накапливаться в почве с годами. Период формирования стебля приходится на более ограниченный период, и переход поглощенного корнями БаП из корневой системы в стебель значительно ниже. Поглощение БаП поверхностью листового аппарата и колоса затруднено из-за микроскопического размера устьиц, препятствующих открытому проникновению пылеватых частиц сажи, содержащих БаП, напрямую в лист, благодаря физиологической структуре пшеницы [45]. Поэтому накопление БаП зерном озимой пшеницы затруднено, что обусловлено работой биохимических барьерных функций залковых.

Типчак, или овсяница валисская, является типичным многолетним пастбищно-кормовым растением степной зоны Ростовской области высотой до 50 см. Накопление БаП происходит равномерно по всем органам растения: разница между минимальным и максимальными значениями содержания БаП в корнях, побегах и соцветиях составляет 7 раз. Содержание БаП в стеблях и соцветиях выше, чем у озимой пшеницы, что связано с особенностями строения и более продолжительным периодом вегетации растения. Поскольку типчак является многолетним растением, накопление БаП происходит регулярно с равномерным распределением в вегетативных и репродуктивных органах растения. Использование типчака для выгула и выпаса животных в зоне максимального загрязнения (площадки № 4, 5) нежелательно.

Накопление корневой системой растений происходит в большей степени, чем наземной частью, как было показано ранее на яровом ячмене [46]. При этом полученные ранее данные о накоплении ПАУ в травянистых растениях тундровой зоны под действием предприятий угледобывающей промышленности согласуется с данными, согласно которым содержание БаП в овсянице овечьей (Festuca ovina) и щучке дернистой (Deschampsia caespitosa) превышало массо- вую долю БаП в органогенном горизонте почв в 1,5-3 раза, соответственно [30]. Почвы тундр обедненные (тундровые поверхностно-глеевые), с толщиной органогенного горизонта до 5 см, в них органическое вещество может находиться в более доступных формах, что оказывает влияние на накопление мхами и лишайниками тяжелых и легких ПАУ [45, 47]. Во мхах Pleurozium schreberi в зоне влияния теплоэлектростанции г. Воркута происходило интенсивное накопление ПАУ, при этом только на поверхности мха концентрировалось до $20 \%$ от всех ПАУ [48]. Такой факт может быть связан с влиянием типа почв: черноземы в степной зоне, вероятно, формируют комплексные соединения с ПАУ, делая их менее доступными для растений. Похожие результаты были получены ранее при моделировании загрязнения почв БаП при выращивании ярового ячменя [46]. С ростом концентрации БаП в почве все морфологические показатели ячменя были ингибированы. Изменение фитотоксичности почв было установлено для энергии прорастания, длины побегов и колоса, веса растений. При этом уровни поглощения БаП корнями ярового ячменя выше, чем в вегетативной части, более чем в 2,5 раза во всех загрязненных вариантах.

\section{Выводы}

1. На основании кластерного анализа выявлены три группы травянистых растений по уровню содержания бенз[а]пирена: слабого - амброзия, пижма, тысячелистник и цикорий; среднего - мятлик, овёс, овсюг, пшеница и полынь; активного накопления - пырей, типчак и тростник. Такое деление во многом объяснялось биоморфологическими особенностями растений. Из всех исследованных видов растений максимальные уровни накопления БаП выявлены для типчака, минимальные - для амброзии.

2. Массовая доля бенз[а]пирена в почвах и растениях закономерно снижалась по мере удаления от Новочеркасской ГРЭС. Максимальное загрязнение было выявлено по трансекте генерального направления, в 1,6 км от Новочеркасской ГРЭС. Наименее загрязненными были площадки, заложенные в восточном направлении.

3. Исследование накопления полиаренов в разных органах растений показало, что наибольшим загрязнением отличались корни всех исследованных видов. Минимальное накопление бенз[а]пирена было характерно для соцветий. Акропетальная направленность в накоплении бенз[а]пирена свидетельствует об активном поглощении полиаренов из почвы.

4. Массовая доля бенз[а]пирена в органогенном горизонте почв значительно превышала его содержание в растениях разных видов, что во многом могло быть связано с особенностями органогенного горизонта, в котором ПАУ могли находиться в связанном состоянии.

Работа выполнена при финансовой поддержке гранта РНФ № 19-74-10046. 


\section{СПИСОК ЛИТЕРАТУРЫ}

1. Геохимия полициклических ароматических углеводородов в горных породах и почвах / А.Н. Геннадиев, Ю.И. Пиковский, В.Н. Флоровская, Т.А. Алексеева, И.С. Козин, А.И. Оглоблина, М.Е. Раменская, Т.А. Теплицкая, Е.И. Шурубор. - М.: Изд-во МГУ, 1996. - 196 с.

2. Ecotoxicological effects of traffic-related pollutants in roadside soils of Moscow / O. Nikolaeva, V. Tikhonov, M. Vecherskii, N. Kostina, A. Astaikina // Ecotoxicology and Environmental Safety. - 2019. - V. 17215. - P. 538-546.

3. Levels, temporal/spatial variations and sources of PAHs and PCBs in soil of a highly industrialized area / S. Yurdakul, I., Çelik M. Çelen, F. Öztürk, B. Cetin // Atmospheric Pollution Research. 2019. - V. 10. - P. 1227-1238

4. PAHs in urban soils of two Florida cities: Background concentrations, distribution, and sources / Yu. Liu, P. Gao, J. Su, E.B. da Silva, L.Q. Ma // Chemosphere. - 2019. - V. 214. P. 220-227.

5. Cabrerizo A., Dachs J., Barceló D. Development of a soil fugacity sampler for determination of air-soil partitioning of persistent organic pollutants under field controlled conditions // Environmental science \& technology. - 2009. - V. 43. - P. 8257-8263.

6. Biodegradation of mixed PAHs by PAH-degrading endophytic bacteria / X. Zhu, X. Ni, M. Waigi, J. Liu, K. Sun, Y. Gao // Int. J. Environ. Res. Public Health. - 2016. - V. 13 (8). - Article number 805 .

7. Degradation of polycyclic aromatic hydrocarbons in a mixed contaminated soil supported by phytostabilisation, organic and inorganic soil additives / A. Wawra, W. Friesl-Hanl, M. Puschenreiter, G. Soja, Th., Reichenauer C. Roithner, A. Watzinger // Science of the Total Environment. - 2018. V. 628. - P. 1287-1295

8. Soil-to-root transfer and translocation of polycyclic aromatic hydrocarbons by vegetables grown on industrial contaminated soils / J. Fismes, C. Perrin Ganier, P. Empereur Bissonnet, J.L. Morel // Journal of Environmental Quality. - 2002. - V. 31. P. 1649-1656.

9. Галиулин Р.В., Башкин В.Н. Особенности поведения стойких органических загрязнителей в системе атмосферные выпадения-растение-почва // Агрохимия. - 1999. - № 12. - С. 69-77.

10. Полициклические ароматические углеводороды в почвах промышленных и селитебных зон Тюмени / Е.Ю. Константинова, С.Н. Сушкова, Т.М. Минкина, Е.М. Антоненко, А.О. Константинов, В.Ю. Хорошавин // Известия Томского политехнического университета. Инжиниринг георесурсов. 2018. - T. 329. - № 8. - C. 66-79.

11. Benzo[a]pyrene contamination in Rostov region of Russian Federation: a 10-year retrospective of soil monitoring under the effect of long-term technogenic pollution / S. Sushkova, T. Minkina, I. Turina, S. Mandzhieva, T. Bauer, I. Zamulina, R. Kizilkaya // Eurasian J. Soil Sci. - 2016. - V. 5 (2). - P. 155-165

12. Bioaccumulation of benzo[a]pyrene nonextractable residues in soil by Eisenia fetida and associated background-level sublethal genotoxicity (DNA single-strand breaks) / A.C. Umeh, L. Panneerselvan, L. Duan, R. Naidu, K.T. Semple // Science of The Total Environment. - 2019. - V. 69115. - P. 605-610.

13. Influence of bacterial community composition and soil factors on the fate of phenanthrene and benzo[a]pyrene in three contrasting farmland soils / Q. Zhu, Y. Wu, J. Zeng, X. Wang, X. Lin // Environmental Pollution. - 2019. - V. 247. - P. 229-237.

14. Doegowska S., Migaszewski Z.M. PAH concentrations in the moss species Hylocomium splendens (Hedw.) B.S.G. and Pleurozium schreberi (Brid.) Mitt. from the Kielce area (southcentral Poland) // Ecotoxicology and Environmental Safety. 2011. - V. 74. - P. 1636-1644.

15. Wu Q., Wang X., Zhou Q. Biomonitoring persistent organic pollutants in the atmosphere with mosses: Performance and application // Environment International. - 2014. - V. 66. - P. 28-37.

16. Active biomonitoring of heavy metals and PAHs with mosses and lichens: a case study in the cities of Naples and London / S. Vingiani, F. de Nicola, W.O. Purvis, E. Concha-Grana, S. Muniategui-Lorenzo, P. Lopez-Mahia, S. Giordano, P. Adamo // Water Air and Soil Pollution. - 2015. - V. 226. - Article number 240 .
17. Air pollution monitoring using emission inventories combined with the moss bag approach / P. Iodice, P. Adamo, F. Capozzi, A.di Palma, A. Senatore, V. Spagnuolo, S. Giordano // Science of the total environment. -2016 . - V. 541. - P. 1410-1419.

18. Airborne petcoke dust is a major source of polycyclic aromatic hydrocarbons in the Athabasca oil sands region / Y.F. Zhang, W. Shotyk, C. Zaccone, T. Noernberg, R. Pelletier, B. Bicalho, D.G. Froese, L. Davies, J.W. Martin // Environmental Science \& Technology. - 2016. - V. 50. - P. 1711-1720.

19. Яковлева Е.В., Габов Д.Н., Безносиков В.А. Временные изменения содержания полиаренов в почвах и растениях нижнего яруса южной тундры под воздействием угледобывающей промышленности // Вестник РУДН. Серия: Экология и безопасность жизнедеятельности. - 2017. - Т. 25. - № 2. - С. 271-293.

20. Белых Л.И. Полициклические ароматические углеводороды в природно-техногенных средах Южного Прибайкалья // Геоэкология. Инженерная геология. Гидрогеология. Геокриология. - 2005. - № 6. - С. 539-551.

21. Characterization of polycyclic aromatic hydrocarbons (PAHs) in vegetables near industrial areas of Shanghai, China: Sources, exposure, and cancer risk / J. Jia, C. Bi, J. Zhang, X. Jin, Z. Chen // Environmental Pollution. - 2018. - V. 241. - P. 750-758.

22. Distribution, transfer, and health risks of polycyclic aromatic hydrocarbons (PAHs) in soil-wheat systems of Henan Province, a typical agriculture province of China / J. Feng, X. Li, J. Zhao, J. Sun // Environmental Science and Pollution Research. - 2017. V. 24. - P. 18195-18203.

23. Accumulation and distribution of PAHs in winter wheat from areas influenced by coal combustion in China / K. Tian, H. Bao, X Liu, F. Wu // Environmental Science and Pollution Research. 2018. - V. 25. - P. 23780-23790.

24. Application of quantitative structure-activity relationship (QSAR) model in comprehensive human health risk assessment of PAHs, and alkyl-, nitro-, carbonyl-, and hydroxyl-PAHs laden in urban road dust / G. Gbeddy, P. Egodawatta, A. Goonetilleke, G. Ayoko, L. Chen // Journal of hazardous materials. -2020 . - V. 383. P. $121-154$.

25. Khalil A., Al-Daoude A. Determination of gamma irradiation effects on polycyclic aromatic hydrocarbons content in wheat brans and endosperms using HPLCIFLT analysis // Journal of Consumer Protection and Food Safety. - 2018. - V. 13. - C. 407-412.

26. Emission characterization, environmental impact, and control measure of PM2. 5 emitted from agricultural crop residue burning in China / H. Zhang, J. Hu, Y. Qi, C. Li, J. Chen, X. Wang, L. Zhang // Journal of Cleaner Production. - 2017. - V. 149. P. 629-635.

27. Демина О.Н. Эколого-биоморфологический анализ степной ценофлоры бассейна Дона // Юг России: экология, развитие. 2011. - № 1. - С. 31-40.

28. Маковская Т.И., Дьячкова С.Г. Органические загрязнители в почвенно-растительном покрове зоны влияния шпалопропиточного производства // Вестник Крас ГАУ. - 2009. - № 6. C. 67-72.

29. PAHs accumulations in plant leaves around coal-fired power plant and identification of their potential use as bioindicators / Q. Yang, T. Luo, J. Yang, H. Chen // Archives of environmental contamination and toxicology. - 2019. - V. 76. - P. 346-355.

30. Полициклические ароматические углеводороды в почвах и растениях нижнего яруса южной кустарниковой тундры в условиях техногенеза / Е.В. Яковлева, Д.Н. Габов, В.А. Безносиков, Б.М. Кондратенок // Почвоведение. - 2014. - № 6. C. $685-696$

31. Яковлева Е.В., Габов Д.Н., Безносиков В.А. Накопление полициклических ароматических углеводородов в растениях тундровой зоны при добыче угля открытым способом // Вестник института биологии РАН. - 2016. - № 4. - С. 24-33.

32. Солнцева М.П., Глазунова К.П. Влияние промышленного и транспортного загрязнения среды на репродукцию семенных растений // Журнал общей биологии. - 2010. - Т. 71. - № 2. C.163-175.

33. Improved biomonitoring of airborne contaminants by combined use of holm oak leaves and epiphytic moss / F. de Nicola, V. Spagnuolo, D. Baldantoni, L. Sessa, A. Alfani, R. Bargagli, F. Monaci, S. Terracciano, S. Giordano // Chemosphere. - 2013. V. 92 . - P. $1224-1230$ 
34. Towards more ecologically realistic scenarios of plant uptake modeling for chemicals: PAHs in a small forest / E. Terzaghi, G. Zacchello, M. Scacchi, G. Raspa, K.C. Jones, B. Cerabolini, A. di Guardo // Science of the Total Environment. - 2015. V. 505. - P. 329-337.

35. Экологические проблемы города Каменска-Шахтинского В.В. Приваленко, В.Т. Мазуренко, В.И. Панасков, Н.В. Мухин. - Ростов н/Д, Изд-во: ЗАО «Цветная печать», 2000. $152 \mathrm{c}$.

36. Ермолаева О.Ю., Мясникова М.А. Флористические особенности залежных участков степей Ростовской области // APRIORI. Серия: Естественные и технические науки. - 2014. - № 3. C. 1-17.

37. Курочкин В.Н. Анализ тенденций развития АПК Ростовской области // Вестник аграрной науки Дона. - 2014. - № 25. C. $56-70$.

38. Fly ash from coal combustion - An environmental source of organic compounds / J. Ribeiro, T.F. Silva, J.G. Mendonca Filho, D. Flores // Applied Geochemistry. - 2014. - V. 44. - P. 103-110.

39. The effect of technogenic emissions on the heavy metals accumulation by herbaceous plants / V. Chaplygin, T. Minkina, S. Mandzhieva, M. Burachevskaya, S. Sushkova, E. Antonenko, E. Poluektov, V. Kumacheva // Environmental Monitoring and Assessment. - 2018. - V. 190. - № 3. - Article number 124.

40. ПНД Ф 16.1:2:2. 2:3. 39-03. МВИ массовой доли бенз[а]пирена в пробах почв, грунтов, донных отложений и твердых отходов методом ВЭЖХ с использованием жидкостного хроматографа «Люмахром». М.: Изд-во «Люмэкс», 2003. - 27 с.

41. ГОСТ 27262-87. Корма растительного происхождения. Методы отбора проб, введ. 1988-07-01. - М.: ИПК Изд-во стандартов, 2002. $-9 \mathrm{c}$.

42. ГОСТ 17.4.4.02-2017. Охрана природы. Почвы. Методы отбора и подготовки проб для химического, бактериологического, гельминтологического анализа. - М.: Стандартинформ, 2018. $-9 \mathrm{c}$

43. Об утверждении перечня наркотических средств, психотропных веществ и их прекурсоров, подлежащих контролю в Российской Федерации. Постановление Правительства Российской Федерации от 30 июня 1998 года № 681 с изменениями на 25 марта 2020 года № 275 (Официальный интернет-портал правовой информации www.pravo.gov.ru, 17.03.2020, N 0001202003170008). - М.: Собрание законодательства Российской Федерации, 1998. - 21 с.

44. Эффективность применения минеральных удобрений при возделывании твердой озимой пшеницы сорта Агат Донской в южной зоне Ростовской области / А.В. Алабушев, А.С. Попов, Г.В. Овсянникова, А.А. Сухарев, Н.Е. Самофалова, Н.С. Кравченко // Зерновое хозяйство России. - 2018. - № 60. - С. 3-9.

45. Участие растений в формировании состава полициклических ароматических углеводородов торфяников / Е.В. Яковлева, Д.Н. Габов, Р.С. Василевич, Н.Н. Гончарова // Почвоведение. - 2020. - № 3. - C. 316-329.

46. Оценка влияния бенз[а]пирена на биологическую активность чернозема Ростовской области / Т.В. Минникова, С.Н. Сушкова, С.С. Манджиева, Т.М. Минкина, С.И. Колесников // Известия Томского политехнического университета. Инжиниринг георесурсов. - 2019. - Т. 330. - № 12. - С. 91-102.

47. Полициклические ароматические углеводороды в мерзлотных бугристых торфяниках криолитозоны / Д.Н. Габов, Е.В. Яковлева, Р.С. Василевич, О.Л. Кузнецов, В.А. Безносиков // Почвоведение. - 2019. - № 9. - С. 1049-1062.

48. Яковлева Е.В., Габов Д.Н. Полициклические ароматические углеводороды в растениях естественных бугристых болот // Принципы экологии. - 2019. - № 32. - С. 119-128.

Поступила 05.12.2020 г.

\section{Информация об авторах}

Сушкова $\boldsymbol{C . H . , ~ к а н д и д а т ~ б и о л о г и ч е с к и х ~ н а у к , ~ с т а р ш и и ̆ ~ н а у ч н ы и ̆ ~ с о т р у д н и к ~ Н а у ч н о - и с с л е д о в а т е л ь с к о г о ~ и н с т и т у - ~}$ та биологии Академии биологии и биотехнологии им. Д.И. Ивановского Южного федерального университета.

$\boldsymbol{Я}$ ковлева $\boldsymbol{E} . \boldsymbol{B}$. , кандидат биологических наук, научный сотрудник лаборатории химии почв отдела почвоведения Институт биологии Федерального исследовательского центра Коми научного центра Уральского отделения Российской академии наук.

Минкина T.M., доктор биологических наук, профессор, заведующая кафедрой почвоведения и оценки земельных ресурсов, главный научный сотрудник Академии биологии и биотехнологии им. Д.И. Ивановского Южного федерального университета.

Габов Д.Н., кандидат биологических наук, старший научный сотрудник экоаналитической лаборатории Институт биологии Федерального исследовательского центра Коми научного центра Уральского отделения Российской академии наук.

Антоненко E.M., кандидат технических наук, старший научный сотрудник кафедры почвоведения и оценки земельных ресурсов Академии биологии и биотехнологии им. Д.И. Ивановского Южного федерального университета.

Дудникова T.C., студент кафедры почвоведения и оценки земельных ресурсов Академии биологии и биотехнологии им. Д.И. Ивановского Южного федерального университета.

Барбашев А.И., студент кафедры почвоведения и оценки земельных ресурсов Академии биологии и биотехнологии им. Д.И. Ивановского Южного федерального университета.

Минникова T.B., кандидат биологических наук, старший научный сотрудник НОЦ «Экология и природопользование» Академии биологии и биотехнологии Южного федерального университета.

Колесников С.И., доктор сельскохозяйственных, профессор, заведующий кафедрой экологии и природопользования Академии биологии и биотехнологии Южного федерального университета.

Paджсnш B.Д., PhD, старший научный сотрудник Научно-исследовательского института биологии Академии биологии и биотехнологии им. Д.И. Ивановского Южного федерального университета. 
UDC [504.43+504.73].054: 547.912

\section{ACCUMULATION OF BENZO[A]PYRENE IN PLANTS OF DIFFERENT SPECIES AND ORGANOGENIC HORIZON OF SOILS OF STEPPE PHYTOCENOSIS UNDER TECHNOGENIC POLLUTION}

\author{
Svetlana N. Sushkova ${ }^{1}$ \\ terra_rossa@mail.ru
}

\section{Evgenia V. Yakovleva²,} kaleeva@ib.komisc.ru

Tatiana M. Minkina ${ }^{1}$, tminkina@mail.ru

Dmitriy N. Gabov2 gabov@ib.komisc.ru

Elena M. Antonenko', antonenko1102@yandex.ru

1 Southern Federal University, 194/1, Stachki avenue, Rostov-on-Don, 344090, Russia.

\author{
Tamara S. Dudnikova ${ }^{1}$, \\ tyto98@yandex.ru
}

Andrey I. Barbashev 1 , barbashev_andrei@mail.ru

Tatiana V. Minnikova ${ }^{1}$, loko261008@yandex.ru

\author{
Sergey I. Kolesnikov ${ }^{1}$, \\ kolesnikov@sfedu.ru
}

Vishnu D. Rajput ${ }^{1}$, rajput.vishnu@gmail.com

2 Institute of Biology of Komi Science Centre of the Ural Branch of the Russian Academy of Sciences, 28, Kommunisticheskaya street, Syktyvkar, 167982, Russia.

The relevance of the research. Despite a significant amount of research of environmental pollution by polyarenes, there is insufficient information on accumulation of polycyclic aromatic hydrocarbons, and in particular the most toxic benzo[a]pyrene, by various types of herbaceous plants, which determines the relevance of research in this direction. The distribution of benzo[a]pyrene over plant organs and organogenic horizons of soils in the Novocherkassk Power Station effect zone was studied.

The main aim was to study the accumulation of benzo[a]pyrene in plants of different species and the organogenic soil horizon of steppe phytocenoses depending on the distance from Novocherkassk Power Station.

Objects. In the coverage area of the Novocherkassk Power Station, the samples of the aerial and root parts of plants and the underlying soil horizons of the organogenic layers were taken to a depth of 0-20 cm. For the study on monitoring sites, dominant species of herbaceous plants: ragweed (Ambrosia artemisiifolia L.), Austrian wormwood (Artemisia austriaca Jack.), noble yarrow (Achillea nobilis L), common chicory (Cichorium intybus L.), common tansy (Tanacetum vulgare L.), creeping wheatgrass (Elytrigia repens (L.) Nevski.) were selected. The cereals: oatmeal (Avena fatua), wheat (Triticum aestivum L.), oats (Avena sativa L.), Wallis fescue or fescue (Festuca valesiaca L.), common reed (Phragmites australis L.), meadow bluegrass (Poap retense L.) were studied as well.

Methods. The content of benzo[a]pyrene in plants was determined by the standard method RD 52.10.556-95 in a modification that allows removing interfering lipid macrocomponents of plants by saponification (saponification method). When benzo[a]pyrene was determined by the method of saponification, the saponifiable lipid fraction was initially removed in the samples by boiling the plant sample in an alcohol solution of alkali, followed by threefold extraction of benzo[a]pyrene with hexane. The basis for determination of benzo[a]pyrene in soils is the PND 16.1:2:2. 2:3. 39-03 technique. Quantitative determination of benzo[a]pyrene in the extract was carried out by high performance liquid chromatography.

The results. Based on cluster analysis, three groups of herbaceous plants were identified by the level of benzo[a]pyrene content: weak, medium, and active accumulation. The maximum levels of benzo[a]pyrene accumulation were found for fescue, and the minimum for ragweed. It was found that the mass fraction of benzo[a]pyrene in soils and plants naturally decreased with distance from the enterprise. Maximum pollution was detected by the transect of the general direction, 1,6 km from the source. The least polluted sites were laid in the eastern direction. A study of polyarenes accumulation in different organs of plants showed that the roots of all the species studied differed the greatest pollution. The mass fraction of benzo[a]pyrene in the organogenic horizon of soils significantly exceeded its content in plants of various species.

Key words:

Benzo[a]pyrene, coal burning, herbaceous plants, soil, bioaccumulation, industrial pollution

The reported research was funded by Russian Foundation for Basic Research project no. 19-74-10046.

\section{REFERENCES}

1. Gennadiev A.N., Pikovskiy Yu.I., Florovskaya V.N., Alekseeva T.A., Kozin I.S., Ogloblina A.I., Ramenskaya M.E., Teplitskaya T.A., Shurubor E.I. Geokhimiya politsiklicheskikh aromaticheskikh uglevodorodov $v$ gornykh porodakh i pochvakh [Geochemistry of polycyclic aromatic hydrocarbons in rocks and soils]. Moscow, MGU Publ., 1996. 196 p.
2. Nikolaeva O., Tikhonov V., Vecherskii M., Kostina N., Astaikina A. Ecotoxicological effects of traffic-related pollutants in roadside soils of Moscow. Ecotoxicology and Environmental Safety, 2019, vol. 17215 , pp. 538-546.

3. Yurdakul S., Celik I., Celen M., Öztürk F., Cetin B. Levels, temporal/spatial variations and sources of PAHs and PCBs in soil of a highly industrialized area. Atmospheric Pollution Research, 2019, vol. 10, no. 4, pp. 1227-1238. 
4. Liu Yu., Gao P., Su J., Da Silva E. B., Ma L. Q. PAHs in urban soils of two Florida cities: Background concentrations, distribution, and sources. Chemosphere, 2019, vol. 214, pp. 220-227.

5. Cabrerizo A., Dachs J., Barceló D. Development of a soil fugacity sampler for determination of air- soil partitioning of persistent organic pollutants under field controlled conditions. Environmental science \& technology, 2009, vol. 43. pp. 8257-8263.

6. Zhu X., Ni X., Waigi M., Liu J., Sun K., Gao Y. Biodegradation of mixed PAHs by PAH-degrading endophytic bacteria. Int. J. Environ. Res. Public Health, 2016, vol. 13, article no. 805.

7. Wawra A., Friesl-Hanl W., Puschenreiter M., Soja G., Reichenauer Th., Roithner C., Watzinger A. Degradation of polycyclic aromatic hydrocarbons in a mixed contaminated soil supported by phytostabilisation, organic and inorganic soil additives. Science of the Total Environment, 2018, vol. 628, pp. 1287-1295.

8. Fismes J., Perrin Ganier C., Empereur Bissonnet P., Morel J.L. Soil-to-root transfer and translocation of polycyclic aromatic hydrocarbons by vegetables grown on industrial contaminated soils. Journal of Environmental Quality, 2002, vol. 31, pp. 1649-1656.

9. Galiulin R.V., Bashkin V.N. Osobennosti povedeniya stojkih organicheskih zagryaznitelej $\mathrm{v}$ sisteme atmosfernye vypadeniyarastenie-pochva [Features of the behavior of persistent organic pollutants in the atmospheric precipitation- plant- soil system] Agrokhimiya, 1999, no.12, pp. 69-77.

10. Konstantinova E.Yu., Sushkova S.N., Minkina T.M., Antonenko E.M., Konstantinov A.O., Horoshavin V.Yu. Polycyclic aromatic hydrocarbons in the soils of industrial and residential zones of Tyumen. Bulletin of the Tomsk Polytechnic University. Geo Assets Engineering, 2018, vol. 329, no. 8, pp. 66-79. In Rus.

11. Sushkova S., Minkina T., Turina I., Mandzhieva S., Bauer T., Zamulina I., Kizılkaya R. Benzo[a]pyrene contamination in Rostov Region of Russian Federation: A 10-year retrospective of soil monitoring under the effect of long-term technogenic pollution. Eurasian J. Soil Sci, 2016, vol. 5, pp.155-165.

12. Umeh A.C., Panneerselvan L., Duan L., Naidu R., Semple K.T. Bioaccumulation of benzo[a]pyrene nonextractable residues in soil by Eisenia fetida and associated background-level sublethal genotoxicity (DNA single-strand breaks). Science of the Total Environment, 2019, vol. 69115, pp. 605-610.

13. Zhu Q., Wu Y., Zeng J., Wang X., Lin X. Influence of bacteria community composition and soil factors on the fate of phenanthrene and benzo[a]pyrene in three contrasting farmland soils. Environmental Pollution, 2019, vol. 247, pp. 229-237.

14. Doegowska S., Migaszewski Z.M. PAH concentration sin the moss species Hylocomium splendens (Hedw.) B.S.G. and Pleurozium schreberi (Brid.) Mitt. from the Kielce area (south-central Poland). Ecotoxicology and Environmental Safe, 2011, vol. 74, pp. 1636-1644.

15. Wu Q., Wang X., Zhou Q. Biomonitoring persistent organic pollutants in the atmosphere with mosses: Performance and application. Environment International, 2014, vol. 66, pp. 28-37.

16. Vingiani S., De Nicola F., Purvis W. O., Concha-Grana E., Muniategui-Lorenzo S., Lopez-Mahia P., Giordano S. Active biomonitoring of heavy metals and PAHs with mosses and lichens: a case study in the cities of Naples and London. Water Air and Soil Pollution, 2015, vol. 226, pp. 1-12.

17. Iodice P., Adamo P., Capozzi F., Di Palma A., Senatore A., Spagnuolo V., Giordano S. Air pollution monitoring using emission inventories combined with the moss bag approach. Science of the Total Environment, 2016, vol. 541, pp. 1410-1419.

18. Zhang Y.F., Shotyk W., Zaccone C., Noernberg T., Pelletier R., Bicalho B., Froese D.G., Davies L., Martin J.W. Airborne petcoke dust is a major source of polycyclic aromatic hydrocarbons in the Athabasca oil sands region. Environmental Science \& Technology, 2016, vol. 50, pp. 1711-1720.

19. Yakovleva E.V., Gabov D.N., Beznosikov V.A. Temporary changes in the content of polyarenes in soils and plants of the lower tier of the southern tundra under the influence of the coal mining industry. Bulletin RUDN. Series: Ecology and Life Safety, 2017, vol. 25, no. 2, pp. 271-293. In Rus.

20. Belyh L.I. Politsiklicheskie aromaticheskie uglevodorody v prirodno-tekhnogennykh sredakh Yuzhnogo Pribaykalya [Polycyclic aromatic hydrocarbons in natural and technogenic environments of the South Baikal region]. Geoekologiya. Inzhenernaya geologiya. Gidrogeologiya. Geokriologiya, 2005, no. 6, pp. 539-551.
21. Jia J., Bi C., Zhang J., Jin X., Chen Z. Characterization of polycyclic aromatic hydrocarbons (PAHs) in vegetables near industrial areas of Shanghai, China: sources, exposure and risk of cancer. Environmental Pollution, 2018, vol. 241, pp. 750-758

22. Feng J., Li X., Zhao J., Sun J. Distribution, transfer, and health risks of polycyclic aromatic hydrocarbons (PAHs) in soil-wheat systems of Henan Province, a typical agriculture province of Chin. Environmental Science and Pollution Research, 2017, vol. 24, pp. 18195-18203.

23. Tian K., Bao H., Liu X., Wu F. Accumulation and distribution of PAHs in winter wheat from areas influenced by coal combustion in China. Environmental Science and Pollution Research, 2018, vol. 25, pp. 23780-23790.

24. Gbeddy G., Egodawatta P., Goonetilleke A., Ayoko G., Chen L. Application of quantitative structure-activity relationship (QSAR) model in comprehensive human health risk assessment of PAHs, and alkyl-, nitro-, carbonyl-, and hydroxyl-PAHs laden in urban road dust. Journal of hazardous materials, 2020, vol. 383, pp. 121-154.

25. Khalil A., Al-Daoude A. Determination of gamma irradiation effects on polycyclic aromatic hydrocarbons content in wheat brans and endosperms using HPLC|FLT analysis. Journal of Consumer Protection and Food Safety, 2018, vol. 13, pp. 407-412.

26. Zhang H., Hu J., Qi Y., Li C., Chen J., Wang X., Zhang L. Emission characterization, environmental impact, and control measure of PM2. 5 emitted from agricultural crop residue burning in China. Journal of Cleaner Production, 2017, vol. 149, pp. 629-635.

27. Demina O.N. Ekologo-biomorfologicheskiy analiz stepnoy tsenoflory basseyna Dona [Ecological and biomorphological analysis of the steppe coenoflora of the Don basin]. Yug Rossii: ekologiya, razvitie, 2011, no. 1, pp. 31-40.

28. Makovskaya T.I., Dyachkova S.G. Organicheskie zagryazniteli v pochvenno-rastitelnom pokrove zony vliyaniya shpalopropitochnogo proizvodstva [Organic pollutants in the soil - vegetation cover of the zone of influence of sleeper impregnation production]. Vestnik Kras GAU, 2009, no.6, pp. 67-72.

29. Yang Q., Luo T., Yang J., Chen H. PAHs accumulations in plant leaves around coal-fired power plant and identification of their potential use as bioindicators. Archives of environmental contamination and toxicology, 2019, no. 76, pp. 346-355.

30. Yakovleva E.V., Gabov D.N., Beznosikov V.A., Kondratenok B.M Polycyclic aromatic hydrocarbons in soils and lower-layer plants of the southern shrub tundra under technogenic conditions. Eurasian Soil Science, 2014, no. 47, pp. 562-572.

31. Yakovleva E.V., Gabov D.N., Beznosikov V.A. Nakoplenie politsiklicheskikh aromaticheskikh uglevodorodov v rasteniyakh tundrovoy zony pri dobyche uglya otkrytym sposobom [Accumulation of polycyclic aromatic hydrocarbons in plants of the tundra zone during open pit coal mining]. Vestnik instituta biologii RAN, 2016, no. 4, pp. 24-33.

32. Solntseva M.P., Glazunova K.P. Influence of industrial and transport pollution of the environment on the reproduction of seed plants. Zhurnal Obshchei Biologii, 2010, vol. 71, no. 2, pp. 163-175. In Rus.

33. De Nicola F., Spagnuolo V., Baldantoni D., Sessa L., Alfani A., Bargagli R., Monaci F., Terracciano S., Giordano S. Improved biomonitoring of airborne contaminants by combined use of holm oak leaves and epiphytic moss. Chemosphere, 2013, vol. 92, pp. 1224-1230.

34. Terzaghi E., Zacchello G., Scacchi M., Raspa G., Jones K.C., Cerabolini B., Di Guardo A. Towards more ecologically realistic scenarios of plant uptake modeling for chemicals: PAHs in a small forest. Science of the Total Environment, 2015, vol. 505, pp. 329-337.

35. Privalenko V.V., Mazurenko V.T., Panaskov V.I., Mukhin N.V. Ekologicheskie problemy goroda Kamenska-Shakhtinskogo [Ecological problems of the city of Kamensk-Shakhtinsky]. Rostov n/D, ZAO «Cvetnaya pechat» Publ., 2000. 152 p.

36. Ermolaeva O.Yu., Myasnikova M.A. Floristicheskie osobennosti zalezhnykh uchastkov stepey Rostovskoy oblasti [Floristic features of fallow plots of the steppes of the Rostov region]. APRIORI. Seriya: Estestvennye i tekhnicheskie nauki, 2014, no. 3, pp.1-17.

37. Kurochkin V.N. Analysis of development trends in the agricultural sector of the Rostov region. Vestnik agrarnoj nauki Dona, 2014, no. 25, pp. 56-70. In Rus.

38. Ribeiro J., Silva T.F., Mendonca Filho J.G., Flores D. Fly ash from coal combustion - an environmental source of organic compounds. Applied Geochemistry, 2014, vol. 44, pp. 103-110. 
39. Chaplygin V., Minkina T., Mandzhieva S., Burachevskaya M., Sushkova S., Antonenko E., Poluektov E., Kumacheva V. The effect of technogenic emissions on the heavy metals accumulation by herbaceous plants. Environmental Monitoring and Assessment, 2018, vol. 190, no. 3, article number 124 .

40. PND F 16.1:2:2. 2:3. 39-03. MVI massovoy doli benz(a)pirena v probakh pochv, gruntov, donnykh otlozheniy i tverdykh otkhodov metodom VEZHKH s ispolzovaniem zhidkostnogo khromatografa «Lyumakhrom» [MVI of the mass fraction of benzo [a] pyrene in samples of soils, soils, bottom sediments and solid waste by HPLC using a Lumahrom liquid chromatograph]. Moscow, Lumex Publ., 2003. $27 \mathrm{p}$

41. GOST 27262-87. Korma rastitelnogo proiskhozhdeniya. Metody otbora prob [State Standart 27262-87. Feed of plant origin. Sampling Methods 1988-07-01]. Moscow, StandardInform Publ., 2002. 9 p.

42. GOST 17.4.4.02-2017. Okhrana prirody. Pochvy. Metody otbora i podgotovki prob dlya khimicheskogo, bakteriologicheskogo, gelmintologicheskogo analiza [State Standart 17.4.4.02-2017. Protection of Nature. Soils. Methods of sampling and sample preparation for chemical, bacteriological, helminthological analysis]. Moscow, Standartinform Publ., 2018. $9 \mathrm{p}$.

43. Ob utverzhdenii perchnya narkoticheskikh sredstv, psikhotropnykh veshchestv $i$ ikh prekursorov, podlezhashchikh kontrolyu $v$ Rossiyskoy Federatsii. Postanovlenie Pravitelstva Rossiyskoy Federatsii ot 30 iyunya 1998 goda № $681 \mathrm{~s} \mathrm{iz}$ meneniyami na 25 marta 2020 goda № 275 (Ofitsialny internet portal pravovoy informatsii www.pravo.gov.ru, 17.03.2020, N 0001202003170008) [On approval of the list of narcotic drugs, psychotropic substances and their precursors subject to control in the Russian Federation. Decree of the Government of the Russian Federation of June 30, 1998 N 681 as amended on
March 25, 2020 No. 275 (Official Internet portal of legal information www.pravo.gov.ru, 03/17/2020, N 0001202003170008)] Moscow, Collection of legislation of the Russian Federation Publ., 1998. $21 \mathrm{p}$.

44. Alabushev A.V., Popov A.S., Ovsyannikova G.V., Sukharev A.A., Samofalova N.E., Kravchenko N.S. Effektivnost primeneniya mineralnykh udobreniy pri vozdelyvanii tverdoy ozimoy pshenitsy sorta Agat Donskoy v yuzhnoy zone Rostovskoy oblasti [The effectiveness of the use of mineral fertilizers in the cultivation of winter hard wheat of the Agat Donskoy variety in the southern zone of the Rostov Region]. Zernovoe hozyaystvo Rossii, 2018, no. 60 , pp. 3-9.

45. Yakovleva E.V., Gabov D.N. Vasilevich R.S., Goncharova N.N. Participation of Plants in the Formation of Polycyclic Aromatic Hydrocarbons in Peatlands. Eurasian Soil Science, 2020, no. 3, pp. 317-329.

46. Minnikova T.V., Sushkova S.N., Mandzhieva S.S., Minkina T.M., Kolesnikov S.I. Evaluation of the effect of benz[a]pyrene on the biological activity of chernozem in the Rostov region. Bulletin of the Tomsk Polytechnic University. Geo Assets Engineering, 2019, vol. 330, no. 12, pp. 91-102. In Rus.

47. Gabov D.N., Yakovleva E.V., Vasilevich R.S., Kuznetsov O.L., Beznosikov V.A. Polycyclic Aromatic Hydrocarbons in Peat Mounds of the Permafrost Zone. Eurasian Soil Science, 2019, no. 9, pp. $1038-1050$.

48. Yakovleva E.V., Gabov D.N. Politsiklicheskie aromaticheskie uglevodorody v rasteniyakh estestvennykh bugristykh bolot [Polycyclic aromatic hydrocarbons in plants of natural tuberous bogs]. Principy ekologii, 2019, no. 32, pp. 119-128.

Received: 5 December 2020.

\section{Information about the authors}

Svetlana N. Sushkova, Cand. Sc., senior researcher, Southern Federal University.

Evgenia V. Yakovleva, Cand. Sc., researcher, IB Komi SC UB RAS.

Tatiana M. Minkina, Dr. Sc., professor, head of the department, Southern Federal University.

Dmitriy N. Gabov, Cand. Sc., senior researcher, IB Komi SC UB RAS.

Elena M. Antonenko, Cand. Sc., senior researcher, Southern Federal University.

Tamara S. Dudnikova, student, Southern Federal University.

Andrey I. Barbashev, student, Southern Federal University.

Tatiana V. Minnikova, Cand. Sc., senior researcher, Southern Federal University.

Sergey I. Kolesnikov, Dr. Sc., professor, head of the department, Southern Federal University.

Vishnu D. Rajput, PhD, senior researcher, Southern Federal University. 